\title{
Textbook on the Desegregation of an Afro-Latinx
}

\section{Grisel Acosta}

\section{Chapter 1}

the red flame flamboyán sitting on top of a Matanzas mountain shelters the hesitant embrace of your light-skinned Mami and negro Papi, open Caribbean Sea before them, ancient gateway, portal, key

\section{Chapter 2}

Abuelo boycotts the wedding porque Papi is too black it will be 20 years before Mami speaks to Abuelito again no one voices the silence at home, so you stay mute, too quiet like a scroll wound so tight it cannot be opened to release its words

\section{Chapter 3}

you make books before you can read, stapled volumes of crayoned letters Mami reads to you every night about Johnny Lion, the exploring cub when you turn three, you read to her, and by five, you've written your first play

but your characters are like Snow White: foreign, cold, trapped

\section{Chapter 4}

Mozart School, in Logan Square, teaches you to be quiet is to die so you better learn to yell and cuss and spit the evil eye, as if 
you were two different people: the one who breaks a girl's glasses for kicking you and

the one who buys school supplies early and scores beyond her grade level on tests

someone quietly submits your name to a magnet school

you don't know who did that, but you take the tests and get in

\section{Chapter 5}

you are bussed to Kenwood Academy, where everyone is Black and they see you as Black, so you go home and ask Mami, "Am I Black?" Mami and Papi look at each other and say nothing, leaving you to take algebra in $7^{\text {th }}$ grade, and watch the rich African American teenagers who drive to school in their parents' Rolls Royces or Jaguars and only

talk to kids who use Coach purses or wear clothes from Marshall Field's leaving you to wonder if you fit in more with the Latino/a wildcats or Black bourgeoisie

\section{Chapter 6}

you learn that the Kenwood college prep program was started to address civil rights issues that were fought for in the 1960s, so you are proud, excited to learn about your history, but your teachers only teach Thoreau, Dickinson, the Greeks, the Holocaust, and you know this is good because they say this is good, but you wonder about García Marquez, and Borges, all the authors on Mami and Papi's bookshelves, and even more so you wonder about

Morrison, and Angelou and Hughes, who are also on Mami and Papi's bookshelves, and

you wonder why Kenwood is great at teaching you discipline and drive but isn't

teaching you about your Latinidad or what seems to be your emerging Blackness

\section{Chapter 7}

you stop paying much attention at school

instead you spend hours listening to Jello Biafra recite lyrics about Cambodian atrocities

RevCo frontman Al Jourgensen pounds beats into you about the Bhopal disaster

X-Ray Spex remind you that your identity does not lie in a false, gendered mirror

you resist the prevailing ' 80 s message that greed is good, while classmates obsess over

gold hoops and getting into Ivy League schools and the latest Bell Biv Devoe 
Mami and Papi fear you because you wear black boots and lipstick and blue and purple bruises from slamdancing with shaved head Mexicanos from La Villita

\section{Chapter 8}

somehow you make it to college, you're even on the college newspaper, and you write

about how a catcalling man on the street said you didn't like him because he was Black, but

you answered, "I am Black," and he said, "You can only be a spic or something"

this idea seems wrong to you and you explain in your newspaper essay that you identify as Black, you claim it, to all of Columbia College Chicago, in black and white print

a professor responds to the essay with a map of the Trans-Atlantic slave trade that shows

most Black slaves were transported to Cuba, Colombia, the Caribbean, South America, your homes, your world is Black

Chapter 9

you go home and tell your parents, "I am clearly Black. Can you please explain this to me? Tell me."

they slowly voice the story about Abuelo's racism, self-loathing, directed at their love

Mami explains how even in her own family there are Black relatives, but they were ostracized, too

you are 22 years old when they finally tell you who you are

you have carried a black and white fissure, like marble stone, inside your stomach,

a rock you've instinctively tried to break with the pounding of flesh and bone under black and white strobe lights, as if the answers were in the extremes of dark and light, dark and light, dark and light

Chapter 10

you are almost 45, an educator of Latinx literature, Afro-Latinidad, la cultura tuya, but

the journey, you are certain now, began when you were bussed to Kenwood, and you saw

yourself in the Black faces of the proud, studious, driven-for-success peers surrounding you there,

and they saw Black you, confused, conflicted, on the edge of danger, and forgave you for not knowing 


\section{Grisel Acosta}

the separation had happened, for maybe they didn't know either, yet there you were, together

like siblings who had drifted off from sea wreckage, finally floating toward each other, ready

to begin a cuento that twists and turns like the salty writhing of a sparkling, multi-hued, crashing

wave with no beginningendseparation, an eternal spiral of knowledge as old as the gold fire in the sky 